\title{
Floral scent of brazilian Passiflora: five species analised by dynamic headspace
}

\author{
DANIEL A.V. MONTERO ${ }^{1}$, MARCIA ORTIZ M. MARQUES ${ }^{2}$, LAURA M.M. \\ MELETTI ${ }^{2}$, MARIA H. VAN KAMPEN ${ }^{3}$ and SANDRA C. POLOZZI ${ }^{4}$ \\ ${ }^{1}$ Faculdade de Ciências Agronômicas, Universidade Estadual Paulista Júlio de Mesquita Filho, \\ Rua José Barbosa de Barros, 1780, Caixa Postal 237, 18610-307 Botucatu, SP, Brasil \\ ${ }^{2}$ Instituto Agronômico, Av. Barão de Itapura, 1481, Caixa Postal 28, 13012-970 Campinas, SP, Brasil \\ ${ }^{3}$ Instituto de Química, Universidade de São Paulo, Av. Prof. Lineu Prestes, \\ 748, Caixa Postal 26077, 05599-970 São Paulo, SP, Brasil \\ ${ }^{4}$ Givaudan do Brasil Ltda, Av. Engenheiro Billings, 2185, Jaguaré, 05321-010 São Paulo, SP, Brasil
}

Manuscript received on May 14, 2015; accepted for publication on December 8, 2015

\begin{abstract}
This study describes for the first time the chemical composition and olfactive description of floral scent from Brazilian Passiflora (Passiflora edulis Sim, Passiflora alata Curtis, Passiflora cincinnata Mast., Passiflora coccinea Aubl. and Passiflora quadrangularis L.). Five species were grown in greenhouse at the Agronomic Institute (IAC), São Paulo, Brazil. Volatile compounds were collected using dynamic headspace. Analyses of scent composition were performed by gas chromatograph coupled to mass spectrometer. Identification of chemical constituents was conducted through of retention index followed by comparative analysis of mass spectra with specialized databases. The olfactive descriptions of floral scent from each species was evaluated for a professional perfumer. High interspecific diversity was found between chemical compositions of floral scent within Passiflora and different bouquets were observed amount the studied species. Mayor constituents were linalool ( $P$. alata), geraniol ( $P$. quadrangularis), 1,4-dimethoxybenzene ( $P$. edulis), benzaldehyde ( $P$. cincinnata) and 2-methyl-3-pentanone ( $P$. coccinea).
\end{abstract}

Key words: chemical composition, fragrances, olfactive description, Passiflora.

\section{INTRODUCTION}

The genus Passiflora L. with more than 500 species described is the largest within the family Passifloraceae (MacDougal and Feuillet 2004). Vast majority of Passiflora species are distributed in Central America and South America, and much rarer in Asia, Australia, and tropical Africa (Dhawan et al. 2004, Ramaiya et al. 2014). Some species

Correspondence to: Marcia Ortiz Mayo Marques

E-mail: mortiz@iac.sp.gov.br have commercial importance and are grown in many countries for fruit production, medicinal use or ornamental purposes (Ulmer and MacDougal 2004). The main centers of Passiflora diversity are found in Colombia and Brazil (Cervi 2006, Ocampo et al. 2007, Ramaiya et al. 2014). Relative abundant literature is available about phytochemistry of Passiflora edulis Sims and P. incarnata L., but only sporadic publications are focused on lest common species. Volatile compounds (VCs) of passion 


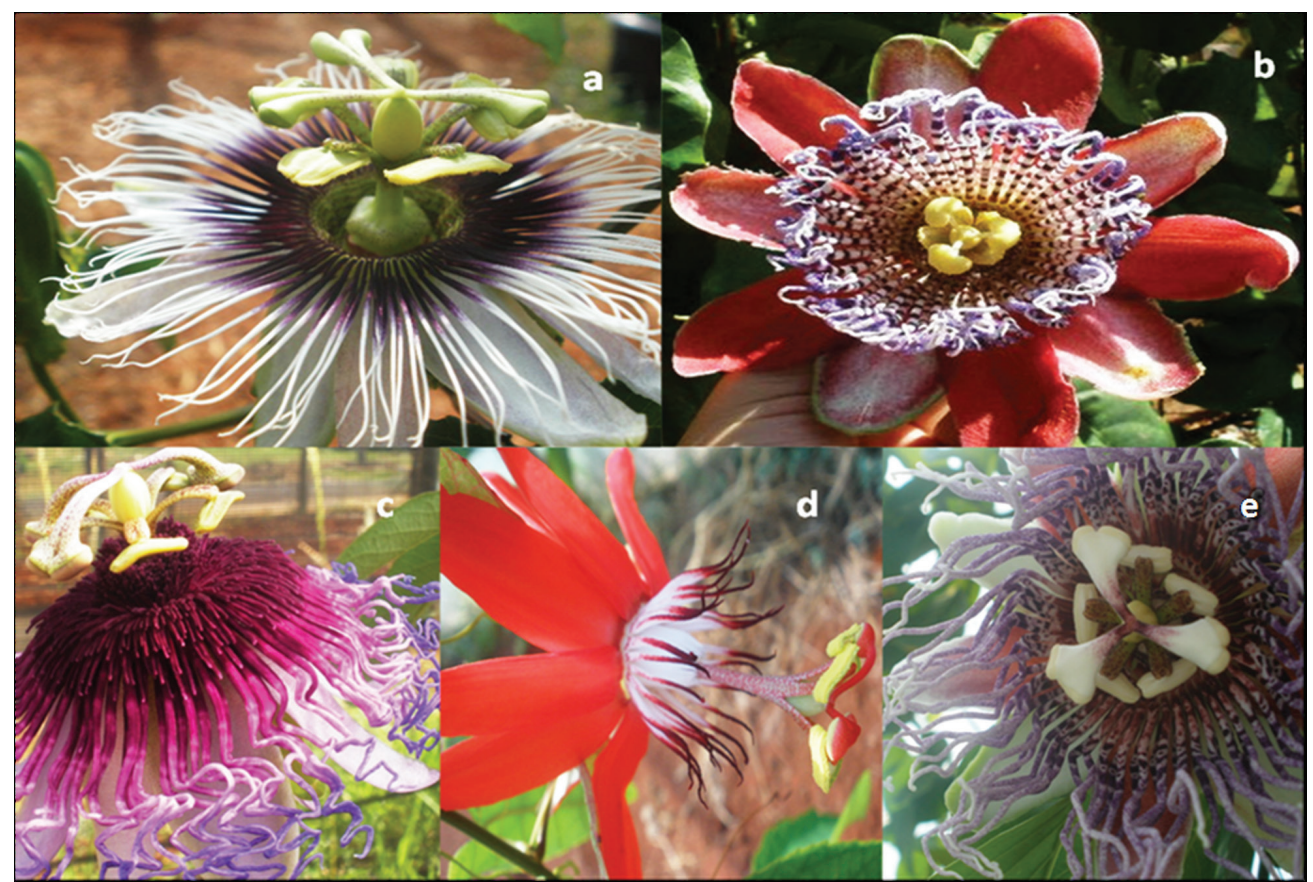

Figure 1 - Species of Passiflora: (a) P. edulis; (b) P. alata; (c) P. cincinnata; (d) P. coccinea; (e) P. quadrangularis. Photo: Daniel A.V. Montero, 2012.

fruit's aroma have been collected and analyzed several times (Galvão et al. 2004, Janzantti et al. 2012, Werkhoff et al. 1998), although floral scent of passionflowers had received little attention. In Brazil, the composition and emission of floral scent in four species of Passiflora from the Atlantic Forest was investigated trough solvent extraction by Varassin et al. (2001); other authors have studied scent emissions by olfactory tests (Amela García 1999, MacDougal 1994, Amela García et al. 2007) and some other works have been focused on the role of floral scent in ecological dynamics like pollination syndromes among Passiflora species (Jazen 1968, Sazima and Sazima 1978, 1987, Koschnitzke and Sazima 1997).

The production of volatile compounds in Passiflora is highly variable and has major ecological importance (Varassin et al. 2001, Amela García et al. 2007). During the last twenty years, the collection and characterization of volatile compounds from live flowers by headspace/gas chromatograph coupled to mass spectrometer (HS/GC-MS) methods. HS/GC-MS methods have been utilized by many researchers to investigate the floral scent of several taxa (Dotterl et al. 2005, Kite and Salazar 2008, Knudsen et al. 2006, Kaiser 2006, Steenhuisen et al. 2012). However, the scent of passionflowers surprisingly, has received little attention in this matter and only the work of Lindberg et al. (2000) have addressed the chemical composition of passionflower's scents by HS/GCMS methods. For this reason, our research was carried out, with the aim of collect, identify and analyze for the first time, the floral fragrances of five Brazilian species of Passiflora: Passiflora edulis Sims, Passiflora alata Curtis, Passiflora cincinnata Mast., Passiflora coccinea Aubl. and Passiflora quadrangularis L. (Figure 1).

\section{MATERIALS AND METHODS}

LOCATION AND PLANT MATERIALS

The research was carried out during the years 20112012 at the Agronomic Institute (IAC), State of São 
Paulo, Brazil. Five Brazilian passionflowers were used: Passiflora edulis, P. alata, P. cincinnata, $P$. coccinea and $P$. quadrangularis. Plant materials were obtained from the Active Bank of Germplasm of the IAC. Seeds were germinated in controlled conditions, following Meletti et al. (2010). After germination seedlings were planted in plastic bags and when reached $60 \mathrm{~cm}$ tall they were transplanted into $30 \mathrm{~L}$ pots. The substrate used for all pots was a mix of $100 \mathrm{~kg}$ of commercial organic substrate, 75 $\mathrm{kg}$ of coconut fibber, $1 \mathrm{~kg}$ of dolomite calcareous, 1 $\mathrm{kg}$ of commercial phosphates and $0.5 \mathrm{~kg}$ of castor bean cake. Fifteen days after the transplant, the young plants were placed in a greenhouse (average temperature of $30^{\circ} \pm 5$ ) adapted with wire lines at $1.70 \mathrm{~m}$ height and they were manually irrigated three times per week. When the plants reached the wire, the apical tissue was cut out to enhance formation of productive curtains, as the traditional passion fruit production system. During the first three months after transplant, foliar fertilization was made every fifteen days as follows: NPK 2814-14 plus micro nutrients $0.1 \mathrm{~g} \mathrm{Fe}, 0.05 \mathrm{~g} \mathrm{Mn}, 0.05$ g Zn, $0.05 \mathrm{~g} \mathrm{Cu}, 0.02 \mathrm{~g} \mathrm{~B}$ and $0.0005 \mathrm{~g}$ Mo.; after the third month, mensal fertilization was made using $100 \mathrm{~g}$ of granulose NPK 20-5-20 per plant. At the beginning of the flowering period $1 \mathrm{~kg}$ of commercial $\mathrm{KCl}$ mixed with the substrate was provided into the pots and during the flowering 15 $\mathrm{mL}$ of liquid NPK $8-8-8$ and $2.5 \mathrm{~mL}$ of $\mathrm{Ca}-\mathrm{Mg}-\mathrm{B}$ were provided every fifteen days.

\section{COLLECTION OF VOLATILE COMPOUNDS}

The floral scent from the flowers of each species was collected with the dynamic headspace technique adapted from Schilling et al. (2010). The traps used to capture the volatile compounds were made of glass tubings (external diameter: $6 \mathrm{~mm}$, internal diameter: $3 \mathrm{~mm}$, length: $1500 \mathrm{~mm}$ ) inside which $100 \mathrm{mg}$ of Porapak Q adsorbent (Supelco, 80-100 mesh) were packed and sealed at the ends with $1 \mathrm{~cm}$ of glass fiber (Supelco, pesticide degree). Before sampling, the traps were successively washed with $10 \mathrm{~mL}$ of methanol (Tedia Brazil, chromatography degree), $10 \mathrm{~mL}$ of dichloromethane (Merck, chromatography degree) and $10 \mathrm{~mL}$ of hexane (Tedia Brazil, chromatography degree) and kept in an oven at $170{ }^{\circ} \mathrm{C}$ for $8 \mathrm{hs}$, under Nitrogen flow (Praxair Inc., 99.99\%) at $32 \mathrm{mLmin}^{-1}$ to ensure the removal of residual compounds.

One flower still attached to the plant was inserted into a glass funnel covered with a polyvinyl bag and the volatile compounds inside the system was captured for 1 hour through of the trap, using a portable vacuum pump with a flow of $100 \mathrm{~mL} \mathrm{~min}$

${ }^{1}$. After sampling, the traps were eluted with $300 \mu \mathrm{L}$ of hexane and ethyl acetate (1:1), chromatography degree (Tedia Brazil). The eluent was collected in a vial (1.5 mL, StepVial II, Sun-Sri) an ice bath and stored in the freezer at $-8^{\circ} \mathrm{C}$ until the analyses of the volatile compounds. For each species were sampled five individuals (one flower per individual), plus a control with vegetative plant material.

\section{CHROMATOGRAPHIC CONDITIONS}

The chemical composition analysis of the floral scents was conducted on a gas chromatograph coupled to mass spectrometer (GC-MS, Shimadzu QP-5000, Kyoto, Japan). Gas chromatograph was equipped with a capillary silica column OV-5 (30 $\mathrm{m} \times 0.25 \mathrm{~mm} \times 0.25 \mu \mathrm{m}$ ) and used the following chromatographic conditions: helium as the carrier gas $\left(1.0 \mathrm{~mL} \mathrm{~min}^{-1}\right)$, injector at $240{ }^{\circ} \mathrm{C}$, splitless injection mode (Splitless time: $0.8 \mathrm{~min}$ ), injected volume was $1 \mu \mathrm{L}$ of solution of the volatile compounds. The OV-5 column temperature was programmed at $35^{\circ} \mathrm{C}$ isotherm for $5 \mathrm{~min}$; and then increased to $180{ }^{\circ} \mathrm{C}$ at a rate $3{ }^{\circ} \mathrm{C} \mathrm{min}^{-1}$, and then increased to $240{ }^{\circ} \mathrm{C}$ at a rate $8{ }^{\circ} \mathrm{C} \mathrm{min}^{-1}$. The mass spectrometer conditions were: ionization voltage $70 \mathrm{eV}$, interface at $230{ }^{\circ} \mathrm{C}$, mass scan range: 35 450 mass units. The identification of the chemical constituents was carried out by comparative 
analysis of mass spectra of the substances with the database system GC-MS (Nist 62.lib), retention index (Adams 1995, 2007) and complementary libraries when needed (NIST Chemistry WebBook, Givaudan database). The retention indices were obtained by injection a series of n-alkanes (SigmaAldrich, $\left.\mathrm{C}_{7}-\mathrm{C}_{24}\right)$ in same conditions indicated above for GC-MS analyses (Van den Dool and Kratz 1963).

Olfactory descriptions of the floral scents of each species were made with help of a professional perfumer.

\section{STATISTICAL ANALYSIS}

Based on the results of chromatographic analysis of fragrances, a graphic of similarity between species was generated by the distance of the correlation coefficient using the cluster analyses of the program BioDiversity Pro version 2. Chemical composition of the fragrances from the studied species were statistically analyzed by the method of principal component analysis also in the program BioDiversity Pro version 2, to describe the data variation between species.

\section{RESULTS AND DISCUSSION}

Each of the studied species showed its own and unique fragrance thanks to its chemical composition, proportion and relative abundance of volatile compounds. The fragrances of the studied species were very intense and pleasant, with the exception of $P$. coccinea which has a floral scent almost imperceptible by the human nose. Forty-six compounds were captured and identified (Table I).

According to similarity analyzes between floral scents of the studied species (Figure

TABLE I

Floral volatiles identified from Passiflora species.

\begin{tabular}{|c|c|c|c|c|c|c|c|}
\hline \multirow[b]{2}{*}{ SUBSTANCES } & \multicolumn{5}{|c|}{$\%$ (average) } & \multirow[b]{2}{*}{$\operatorname{IRexp}^{\mathrm{a}}$} & \multirow{2}{*}{$\begin{array}{l}\text { Identification } \\
\text { method }^{\mathrm{b}}\end{array}$} \\
\hline & $\underset{\text { alata }}{P .}$ & $\begin{array}{c}P . \\
\text { cincinnata }\end{array}$ & $\begin{array}{c}P . \\
\text { coccinea }\end{array}$ & $\begin{array}{c}P . \\
\text { edulis }\end{array}$ & $\begin{array}{c}P . \\
\text { quadrangularis }\end{array}$ & & \\
\hline \multicolumn{8}{|l|}{ Alyphatic } \\
\hline 2-methyl-3-pentanone & 2.2 & 14.5 & 16.3 & 4.7 & 2.8 & - & $\mathrm{a}$ \\
\hline heptane & 0.7 & 2.5 & 8.1 & 1.6 & 2.7 & 702 & $a, b$ \\
\hline methyl isobutyl ketone & - & - & - & 0.3 & - & 716 & $a, b$ \\
\hline 2,5-dimethyl-2-hexene & 1.9 & 9.6 & 8.8 & 4.2 & - & 745 & $a, b$ \\
\hline isobutyl acetate & - & 2.2 & - & 2.4 & - & 768 & $a, b$ \\
\hline allyl acetate & 0.9 & - & - & 3.0 & 2.2 & 785 & $\mathrm{a}$ \\
\hline 2-hexanone & - & 5.9 & 5.6 & - & 0 & 787 & $a, b$ \\
\hline octane & - & 2.6 & - & - & 0 & 792 & $a, b$ \\
\hline 2-hexanol & 1.9 & - & 2.7 & - & 2.5 & 797 & $a, b$ \\
\hline 3-hexyl-hydroperoxide & - & 2.7 & 2.1 & 0.8 & 1.2 & 801 & $\mathrm{a}$ \\
\hline 3-penten-2-ol & - & 3.6 & - & 1.3 & - & 806 & $\mathrm{a}$ \\
\hline butyl acetate & - & - & - & 5.4 & - & 814 & $a, b$ \\
\hline 4-methyl-octane & - & 1.9 & - & - & - & 863 & $a, b$ \\
\hline decane & - & - & - & 0.1 & - & 1000 & $a, b$ \\
\hline 2,4-dimethyl-decane & - & 7.9 & - & 1.2 & - & 1060 & $\mathrm{a}$ \\
\hline undecane & - & 5.5 & 3.5 & 0.5 & - & 1103 & $\mathrm{a}, \mathrm{b}$ \\
\hline dodecane & - & - & 15.9 & 2.7 & - & 1201 & $\mathrm{a}, \mathrm{b}$ \\
\hline
\end{tabular}


TABLE I (continuation)

\begin{tabular}{|c|c|c|c|c|c|c|c|}
\hline \multirow[b]{2}{*}{ SUBSTANCES } & \multicolumn{5}{|c|}{$\%$ (average) } & \multirow[b]{2}{*}{$\operatorname{IRexp}^{a}$} & \multirow{2}{*}{$\begin{array}{c}\text { Identification } \\
\operatorname{method}^{\mathrm{b}}\end{array}$} \\
\hline & $\begin{array}{c}P . \\
\text { alata }\end{array}$ & $\begin{array}{c}P . \\
\text { cincinnata }\end{array}$ & $\begin{array}{c}P . \\
\text { coccinea }\end{array}$ & $\begin{array}{l}P . \\
\text { edulis }\end{array}$ & $\begin{array}{c}P . \\
\text { quadrangularis }\end{array}$ & & \\
\hline tridecane & - & 2.4 & - & 0.6 & - & 1286 & $a, b$ \\
\hline tetradecane & - & - & 14.8 & 2.1 & - & 1403 & $\mathrm{a}, \mathrm{b}$ \\
\hline hexadecane & - & - & 4.3 & 2.0 & - & 1605 & $a, b$ \\
\hline TOTAL & 7.6 & 61.3 & 82.1 & 32.9 & 11.4 & & \\
\hline \multicolumn{8}{|l|}{$\begin{array}{l}\text { Benzenoids and } \\
\text { Phenylpropanoids }\end{array}$} \\
\hline benzaldehyde & - & 14.7 & - & - & - & 956 & $a, b$ \\
\hline benzyl alcohol & 1.2 & - & - & 1.4 & 0.9 & 1032 & $a, b$ \\
\hline phenylethylalcohol & - & 2.4 & - & - & 2.7 & 1110 & $a, b$ \\
\hline 4-ethyl-benzaldehyde & trace & 3.5 & - & 1.7 & 2.4 & 1161 & $a, b$ \\
\hline 1,4-dimethoxybenzene & 6.2 & - & - & 44.7 & - & 1163 & $a, b$ \\
\hline $\begin{array}{l}\text { 3,4-dimethylaceto } \\
\text { phenone }\end{array}$ & 0.5 & 2.7 & - & 1.1 & 1.6 & 1281 & $a, b$ \\
\hline trans-methyl cinnamate & - & - & - & 5.9 & 2.6 & 1382 & $a, b$ \\
\hline 1,3,5-trimethoxy-benzene & - & - & - & 2.1 & - & 1409 & $a, b$ \\
\hline prenyl benzoate & - & - & - & - & 0.3 & 1487 & a \\
\hline benzyltiglate & - & - & - & - & 10.9 & 1502 & $a, b$ \\
\hline $\begin{array}{l}\text { 4-methyl-2,6-di-tert- } \\
\text { butylphenol }\end{array}$ & - & - & 3.0 & - & - & 1514 & $a, b$ \\
\hline 2-phenylethyltiglate & - & - & - & - & 1.5 & 1589 & $a, b$ \\
\hline TOTAL & 7.9 & 23.3 & 3.0 & 56.9 & 22.9 & & \\
\hline \multicolumn{8}{|l|}{ Monoterpenes } \\
\hline mircene & 0.4 & - & - & - & 2.0 & 992 & $a, b$ \\
\hline limonene & 0.2 & - & - & 0.7 & 1.6 & 1026 & $a, b$ \\
\hline eucalyptol & - & - & - & 0.5 & 0 & 1027 & $\mathrm{a}, \mathrm{b}$ \\
\hline cis-ocimene & - & - & - & - & 1.5 & 1040 & $a, b$ \\
\hline trans-ocimene & 1.0 & - & 2.7 & - & 3.7 & 1049 & $a, b$ \\
\hline linalool & 40.2 & 0.9 & - & - & 1.2 & 1102 & $a, b$ \\
\hline citronellal & 0.4 & - & - & - & - & 1151 & $a, b$ \\
\hline nerol & 0.3 & - & - & - & 1.4 & 1229 & $a, b$ \\
\hline citronellol & 22.4 & - & - & - & - & 1231 & $a, b$ \\
\hline neral & 4.5 & - & - & - & - & 1242 & $a, b$ \\
\hline iso-geraniol & 1.2 & - & - & - & - & 1250 & $a, b$ \\
\hline geraniol & 1.4 & - & - & - & 43.6 & 1254 & $a, b$ \\
\hline geranial & 7.8 & - & - & - & 1.6 & 1272 & $a, b$ \\
\hline methyl geranate & 2.0 & - & - & - & 0.9 & 1326 & $a, b$ \\
\hline TOTAL & 81.8 & 0.9 & 2.7 & 1.2 & 57.5 & & \\
\hline TOTAL IDENTIFIED & 97.3 & 85.5 & 87.8 & 91.0 & 91.8 & & \\
\hline
\end{tabular}

${ }^{a}$ IR (retention indices), comparison of RIs with reported in the literature (NIST Chemistry WebBook, Adams 2007, 1995).

${ }^{\mathrm{b}}$ Identification method: $\mathrm{a}$ - mass spectra analyses; $\mathrm{b}$ - mass spectra and retention indices analyses. 
$2)$, two groups were associated. Close related species $P$. alata and $P$. quadragularis formed the first group with $77 \%$ of similarity between the compositions of their fragrances, both rich and dominated by monoterpenes. The other group was formed by the other three species, with higher similarity between $P$. cincinnata and P. edulis. This could be explained by the large proportion of benzenoids and phenylpropanoids present on the floral scents of these species. Moreover, $P$. coccinea was associated in this group but placed in the middle of the clad, since the fragrance of this species is mainly constituted by aliphatic compounds, also present in all the other studied species. The PC1 discriminated the species with monoterpenes as major constituents ( $P$. alata and $P$. quadrangularis), and the PC2 discriminated the species with benzenoids and phenylpropanoids as major constituents ( $P$. edulis and $P$. cincinnata). The principal component analyses (PCA) based on volatile compounds from different metabolic pathways explained $82 \%$ of variance between the studied species (Figure 3).

FLORAL SCENT OF P. alata

Based on the GC-MS analysis of the flower scent of $P$. alata, 21 compounds were identified. This fragrance consists primarily of terpenoids $(81.8 \%)$, benzenoids and phenylpropanoids (7.9\%) and aliphatic compounds (7.6\%). Linalool (40.2\%) and citronellol (22.4\%) were the main constituents of fragrance. Olfactive description: rich and very interesting mix of white flower, fresh rose and very powerful citrus fruity notes and sub notes of honey with a creamy velvet undertone. This was a very elegant fragrance which cached our attention for further research.

FLORAL SCENT OF P. cincinnata

In the floral scent of $P$. cincinnata 17 compounds were captured, identified and classified. The aliphatic compounds had the largest proportion (61.3\%) with 12 identified compounds. Although the fragrance of $P$. cincinnata also presented a high proportion of benzenoids and phenylpropanoids (23.3\%) of which five compounds were identified, including benzaldehyde (14.7\%) as one of the main constituents. Only one terpenoid was identified (linalool) responsible for the $0.9 \%$ of the fragrance. Olfactive description: powerful white flower and a strong faint cresolic odor, intensely sweet, with an undertone of sweet crushed bitter almond, nut like, aspects of gardenia and mimosa flowers, sub notes of honey.

\section{FLORAL SCENT OF $P$. coccinea}

We noted that the flowers of $P$. coccinea emitted a fragrance so subtle that it was almost imperceptible for our noses, unless getting really close to the flower. However, a number of volatile compounds were collected in the headspace of these flowers. The flower scent composition of $P$. coccinea was primarily given by 10 aliphatic compounds $(82.1 \%)$. In addition, two unidentified compounds constituted $5.2 \%$ of the fragrance. Major constituent of this fragrance was 2-methyl-3-pentanone (16.3\%). Olfactive description: Weak mostly absent smell. Spots of vanillin and raspberry ketone.

\section{FLORAL SCENT OF P. edulis}

We captured, identified and classified 24 compounds belowing to the floral scent of this species. Most of the fragrance was made by six benzenoids and phenylpropanoids (56.9\%).The compound 1,4-dimethoxybenzene (also known as dimethyl hydroquinone in the perfume industry) had the highest proportion in the fragrance (44.7\%). The aliphatic compounds (32.9\%) were the most diverse with 15 identified compounds. Interestingly, terpenoids only constituted $1.2 \%$ of the fragrance. Olfactive description:white flower, aspects of Ylang-Ylang, balsamic, anysic, carnation (eugenol, 

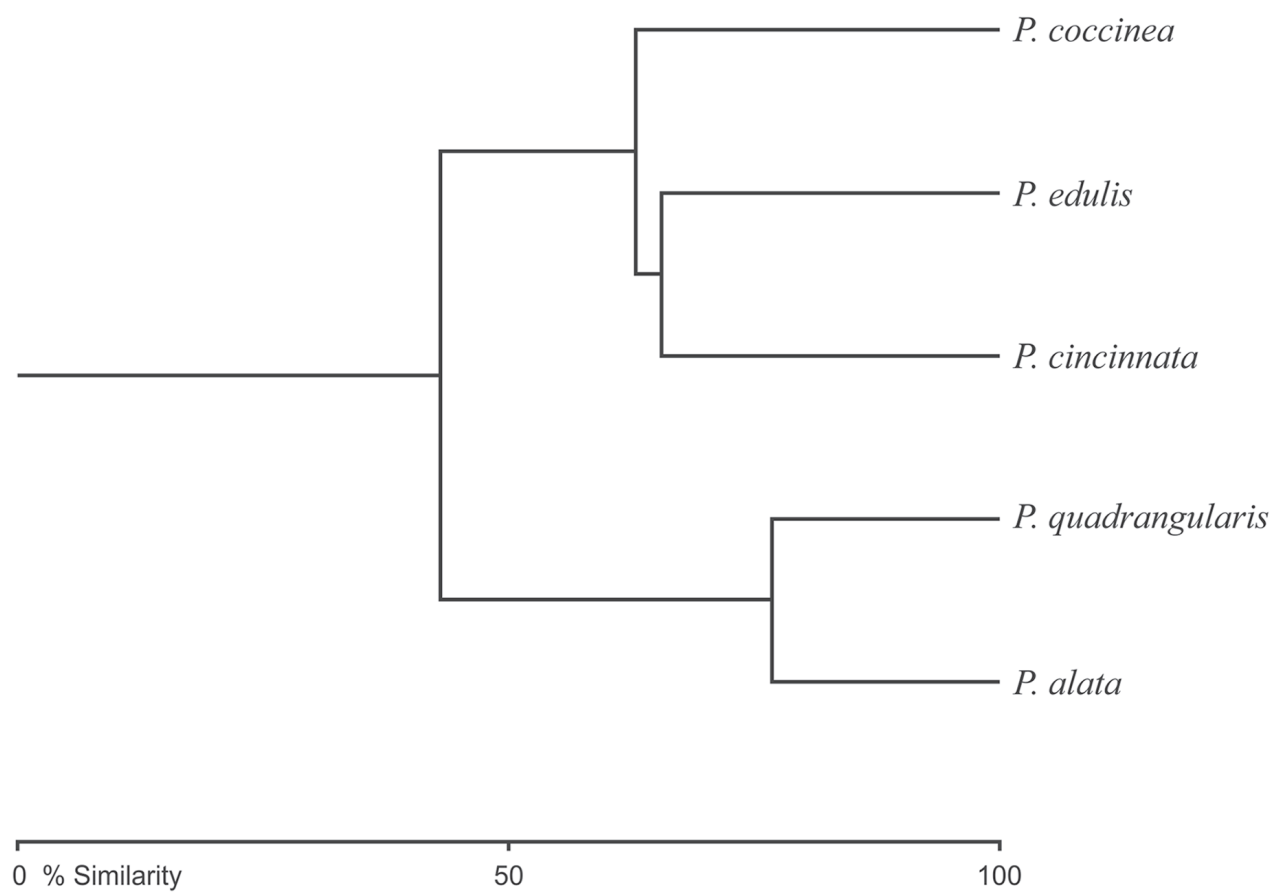

Figure 2 - Cluster analyze of similarity among floral scents of Passiflora species from Brazil.

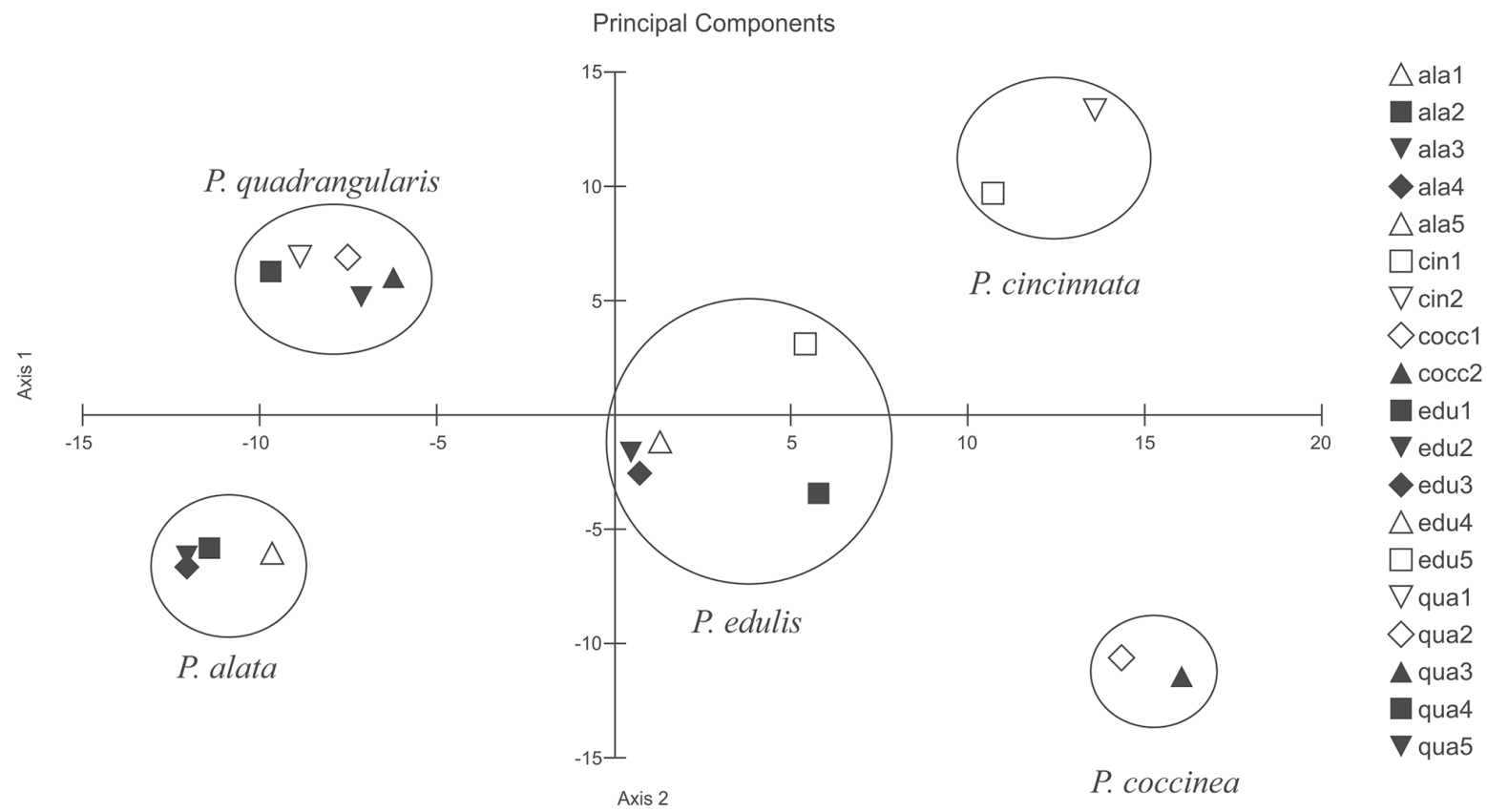

Figure 3 - Principal component analyses of floral scent of Passiflora based on volatile compounds. 
heliotropine), animalic (creolic, methyl benzoate notes) with citric freshness of pamplemouse.

FLORAL SCENT OF P. quadrangularis

In the floral scent of $P$. quadrangularis, 22 compounds were identified. Floral scent was mainly constituted by nine terpenoids $(57.5 \%)$ and nine benzenoids and phenylpropanoids (22.9\%). Also, five aliphatic compounds (11.4\%) were identified. The major compound of this fragrance was the geraniol (43.6\%). Olfative description: velvet pinene odor. Ozone, sparkling / apple watermelon fruity notes. Has sulfur undertones with Rosyfloral-aldehydic-faint accord and rounded off by special fruitiness. Floral Fruity, Rose and Peach.

According to Amela García et al. (2007), the floral biology of approximately 23 species of Passiflora has been studied, although more than 525 species have been described (MacDougal and Feuillet 2004). At least 30 of these species produce floral fragrances perceivable by the human nose (see citation in Amela García et al. 2007), yet, until the year 2012, the volatile compounds of only a few species (c.a 12) of Passiflora had been identified (Lindberg et al. 2000, Varassin et al. 2001). Besides, olfactory tests with floral parts of nine species have been conducted, showing that the odors comprising the floral fragrances are emitted by different parts of the flower, particularly by the corona filaments (radii) in which the secretory tissue involves the entire perimeter of each filament (Amela García et al. 2007). Absence of fragrances also, has been reported in several species (Vanderplank 1996, Koschnitzke and Sazima 1997, Amela García 1999), including P. edulis (Lindberg et al. 2000), curiously. In our research $P$. edulis presented an intense fragrance very rich in benzenoids that may have a key function in pollination by carpenter bees, well documented for this specie (Meletti et al. 2010).
Like it was observed by Lindberg et al. (2000), the floral scent of the studied passionflowers had the volatile substances from the three main biosynthetic pathways of the secondary metabolism of plants: i.e. fatty acid derivatives of the polyketide; benzenoids from the shikimic acid; and isoprenoids of the mevalonic acid pathways. Most of these compounds are commonly found in floral scents of other species (Kaiser 1993, Knudsen et al. 2004) and its function as important signals for communication between plants and other organisms has been well documented (Raguso et al. 2003, Knudsen et al. 2006, Soler et al. 2011). The volatile compounds found by Lindberg et al. (2000) in P. ligularis, P. riparia and P. maliformis among other species of Passiflora which were also found in our research, included: benzaldehyde $(P$. cincinnata), benzylalcohol (P. alata, $P$. edulis and $P$. quadrangularis), 1,3,5-trimethoxybenzene ( $P$. edulis), citronellol (P. alata), linalool (P. alata, $P$. quadrangularis and $P$. cincinnata), transocimene ( $P$. alata and $P$. coccinea) and myrcene, nerol, geraniol and geranial ( $P$. alata and $P$. quadrangularis).

\section{CONCLUSIONS}

The chemical compositions of the floral fragrances from the studied species had large interspecific diversity, as well as interesting potential in the fragrance industry. Fragrances of $P$. alata and $P$. quadrangularis were very interesting mixes of floral and fruity notes with creamy sub notes and variable undertones. The main substances found were linalool for $P$. alata, benzaldehyde for $P$. cincinnata, 2-methyl-3-pentanone for $P$. coccinea, 1,4-dimethoxybenzene for $P$. edulis and geraniol for P. quadrangularis.

\section{ACKNOWLEDGMENTS}

The authors thank Coordenação de Aperfeiçoamento de Pessoal de Nível Superior (CAPES)/ Conselho 
Nacional de Desenvolvimento Científico e Tecnológico (CNPp) (PEC-PG 190609/2010-9) for Master's Degree fellowship to the lead author Daniel AntonioVillamil Montero.

\section{REFERENCES}

ADAMS RP. 1995. Identification of Essential Oil Components by Gas Cromatography/Mass Spectroscopy. $2^{\text {nd }}$ ed., Illinois:Allured Pub Corp, 456 p.

ADAMS RP. 2007. Identification of Essential Oils Components by Gas Chromatography/Mass Spectrometry, $4^{\text {th }}$ ed., Illinois: Allured Pub Corp, 804 p.

AMELA GARCÍA MT. 1999. Biología floral y sistema reproductivo de especies nativas de Passiflora (Passifloraceae) de la Argentina.Tesis de doctorado, Universidad de Buenos Aires, Buenos Aires, $286 \mathrm{p}$.

AMELA GARCÍA MT, GALATI BG AND HOC PS. 2007. Ultrastructure of the corona of scented and scentless flowers of Passiflora spp. (Passifloraceae). Flora 202: 302-315.

CERVI AC. 2006. O gênero Passiflora L. (Passifloraceae) no Brasil, espécies descritas após o ano de 1950. Adumbr Summae Ed 16: 1-5.

DHAWAN K, DHAWAN S AND SHARMA A. 2004. Passiflora: a review up date. J Ethnopharmacol 94: 1-23.

DOTTERL S, WOLFE LM AND JURGENS A. 2005. Qualitative and quantitative analyses of flower scent in Silene latifolia. Phytochemistry 66: 203-213.

GALVÃO M, NARAIN N, ALMEIDA J, MADRUGA MS AND BRITO ES. 2004. Compostos voláteis dos frutos de maracujá (Passiflora edulis f. flavicarpa) e de cajá (Spondias mombin L.) obtidos pela técnica de headspace dinâmico. Ciênc Tecnol Aliment 24(2): 212-216.

JAZEN H. 1968. Reproductive behaviour in the Passifloraceae and some of its pollinators in Central America. Behaviour 32: 33-48.

JANZANTTI NS, MACORIS MS, GARRUTI SD AND MONTEIRO M. 2012. Influence of the cultivation system in the aroma of the volatile compounds and total antioxidant activity of passion fruit. Food Sci and Technol 46: 511-518.

KAISER R. 1993. The scent of orchids - olfactory and chemical investigations. Amsterdam: Elsevier, Netherlands, 260 p.

KAISER R. 2006. Meaningful scents around the world: olfactory, chemical, biological, and cultural considerations. Zürich: Verlag, Helv Chim Acta, 304 p.

KITE GC AND SALAZAR GS. 2008. Chemical composition of the inflorescence odor of Malaxis rzedowskiana (Orchidaceae). Rev Mex Biodivers 79: 153-157.
KNUDSEN JT, ERIKSSON R, GERSHENZON J AND STAHL B. 2006. Diversity and distribution of floral scent. Bot Rev 72: 1-120.

KNUDSEN JT, TOLLSTEN L, GROTH I, BERGSTRÖM G AND RAGUSO RA. 2004. Trends in floral scent chemistry in pollination syndromes: floral scent composition in hummingbird-pollinated taxa. Bot J Linn Soc 146: 191-199.

KOSCHNITZKE C AND SAZIMA M. 1997. Biologia floral de cinco espécies de Passiflora L. (Passifloraceae) em mata semidecídua. Rev Brasil Bot 20: 119-126.

LINDBERG AB, KNUDSEN JT AND OLESEN JM. 2000. Independence of floral morphology and scent chemistry as trait groups in a set of Passiflora species. Det Norske Videnskaps-Akademi. I Mat Naturvidenskapelige Klasse, Skrifer, Ny Serie 39: 91-111.

MACDOUGAL JM. 1994. Revision of Passiflora subgenus Decaloba section Pseudodysosmia (Passifloraceae). Syst Bot Monogr 41: 1-146.

MACDOUGAL JM AND FEUILLET C. 2004. Systematics. In: Ulmer T and MacDougal JM (Eds), Passiflora: passionflowers of the World, Cambridge: Timber Press, p. 27-31.

MELETTI LMM, OLIVEIRA JC AND RUGGIERO C. 2010. Maracujá. (Série Frutas Nativas 6). Jaboticabal: Funep, 55 p.

OCAMPOJ, COPPENSD'EECKENBRUGGEG, RESTREPO M, JARVIS A, SALAZAR M AND CAETANO CM. 2007. Diversity of Colombian Passifloraceae: biogeography and an updated list for conservation. Biota Colombiana 8: 1-45.

RAGUSO RA, LEVIN RA, FOOSE SE, HOLMBERG MW AND MCDADE LA. 2003. Fragrance chemistry, nocturnal rhythms and pollination "syndromes" in Nicotiana. Phytochemistry 63: 265-284.

RAMAIYA AD, BUJANG JS AND ZAKARIA MH. 2014. Genetic Diversity in Passiflora Species Assessed by Morphological and ITS Sequence Analysis. The Scien World J 1: 11.

SAZIMA M AND SAZIMA I. 1978. Batpollination of the passion flower, Passiflora mucronata, in Southestern Brazil. Biotropica 10: 100-109.

SAZIMA M AND SAZIMA I. 1987. Aditional observations on Passiflora mucronata, the bat-pollinated passionflower. Cien Cult 39: 310-312.

SCHILLING B, KAISER R AND NATSCH A. 2010. Investigation of odors in the fragrance industry. Chemoecology 20: 135-147.

SOLER C, HOSSAERT-MCKEY M, BUATOIS B, BESSIÈRE JM, SCHATZ B AND PROFFIT M. 2011. Geographic variation of floral scent in a highly specialized pollination mutualism. Phytochemistry 72: 74-81.

STEENHUISEN SL, RAGUSO RA AND JOHNSON SD. 2012. Floral scent in bird- and beetle-pollinated Protea species (Proteaceae): Chemistry, emission rates and function. Phytochemistry 84: 78-87. 
ULMER T AND MACDOUGAL JM. 2004. Passiflora: passionflowers of the world. Cambridge: Timber Press, $430 \mathrm{p}$.

VAN DEN DOOL H AND KRATZ DJ. 1963. A generalization of the retention index system incluing liner temperature programmed gas-liquid partition chromatography. J Cromatogr 11: 463-467.

VANDERPLANK J. 1996. Passiflora quadrifaria. Curtis's Botanical. Magazine 13: 63-69.
VARASSIN IG, TRIGO JR AND SAZIMA M. 2001. The role of nectar production, flower pigments and odour in the pollination of four species of Passiflora (Passifloraceae) in south-easthern Brazil. Bot J Linn Soc 136: 139-152.

WERKHOFF P, GUNTERT M, KRAMMER G, SOMMER

H AND KAULEN J. 1998. Vacuum headspace method in aroma research: Flavor chemistry of yellow passion fruits. J Agric Food Chem 46: 1076-1093. 